Various degencracies like those already mentioned are liable to occur, especially those in which connective tissue in general is predisposed. The fibers are observed in bundles, closely packed together, with many connective tissue corpuscles shown at intervals. Fibroid degeneration is easily distinguished from the other degeneracies of the pulp (Fig 11).

In these cases, the blood vesscls and nerve tissue are relatively few. 'The blood vessels remaining usualiy have thickened walls, especially in the external and middle coats. This, of course, narrows the lumn. Not infrequently the blood vessels are entirely obliterated. These fibroma:, very common in exposed pulps, are not now under consideration. In nearly if not all of these degenerations the blood vessels are first involved, later nerve tissue.

All these degenerations, including the pathologic processes of evolution, are the direct constitutional cau:es of tooth decay, crosion and abrasion brought about by diminution of tooth vitality.

Notw,-The discussion on the papers of Drs. Andrews, Talbot and I atham will follow the paper of Dr. Latham, which will appear August 20.

\section{TUBERCULOSIS IN THE JEWISH DISTRICT OF CHICAGO.}

THEODORE B. SACHS, M.D.

Instructor Interval Medicine College of Physicians and Surgeons; Examining I'hysician Maternal Jewish Hospital for Consumptives; Attending Physician Cook County Hospital. CHICAGO.

The Jewish population of Chicago can be estimated at 75,000 . This element of population is not as homogeneous as any other of the numerous nationalities found in this city; the ideas, customs and mode of life of Jews differ according to their place of nativity or length of residence in this country. The so-called immunity of the Jewish race from certain diseases varies in degree according to the economic and hygienic conditions in which they live; tuberculosis, for instance, may be comparatively rare among the wellto-do, but is very common among the poor. The same can be said about all kinds of infectious diseases, the spread of which is favored by poverty, overcrowding and its attendant unfavorable conditions of life. Conditions in which the different elements of the Jewish population live influence the degree of prevalence of certain diseases to a much greater extent than any racial characteristics.

THE JEWISH DISTRTCT OF CHICAGO; ITS AREA AND POPULATION.

The largest percentage of the Jewish poor of Chicago are found in a district bounded by Canal Street on the east, Blue Island Avenue west, Taylor Street north and Fourteenth Place south (Chart 1). This area measures 244.6 acres and corresponds to one-half of the Ninth and a fraction of the Nineteenth wards of this city.

Its population can be estimated at 31,000 , of which 22,500 are Jews. The Russian Jew represents the predominant element; Jews from Austro-Hungary, German Poland, Roumania and other European countries are in the minority.

All trades are represented here to a certain extent. Tailor-trade and work in factories and stores furnish means of subsistence to the greatest number. Of men engaged in outdoor work the largest percentage are peddlers.

Constant emigration from this district of the Americanized and more prosperous Jewish element is compensated by a continuous influx of new immigrants; thus the general aspect of this part of the city remains about the same. The non-Jewish population is found chiefly at the outer belt of this district and consists of Bohemians, Italians, Irish and a sinall number of Lithuanians and Poles.

\section{IIYGIENIC CONDITIONS. MIODE OF LIFE.}

The air in this part of the city is constantly filled with dust and clouds of smoke from the vast number of factories, foundries and railroads of the adjacent river district. It is further polluted by emanations from piles of refuse accumulating in streets and alleys. A large portion of this area is but seldom swept or sprinkled. There is only one small playground and no parks in sight for a distance of three miles. Hunger for pure air is the cry of the neighborhood. A more comprehensive idea of the existing conditions was gained by a detailed study of a square block in the center of this district (Chart 2), in which a house-tohouse investigation was made by myself and Miss Bertha Hazard, a resident of the Hull House. This block is bounded by Jefferson street on the east, Union Street west, Maxwell Street 'south, and O'Brien Street north. West Thirteenth Street, one of the narrowest streets in Chicago, runs through its center. The area measures eight acres and has a population of $2,00 \%$ Jews and 214 non-Jews, or about 278 people per acre. Sixty-six per cent. of buildings are two stories high. ${ }^{1}$ Forty-five per cent. of population in this square block live in rear flats, rear buildings or basements. The position of buildings is such that very little or no light can enter through the windows on either side. The average family consists of parents and four children. Three or four-room flats are the general rule. Extreme poverty compels a large number of families to utilize only half of their rooms during the cold season. Windows are generally kept closed through the entire winter. The extremely unsanitary conditions in which these people work and live, their abject poverty and overcrowding would naturally lead to a high rate of mortality from all diseases, but the effect of these unfavorable conditions is greatly mitigated by certain features of Jewish life, among which I could mention their early marriages, chastity, rarity of syphilis and alcoholism, easy access to medical aid. tendency to consult a physician for the most trivial ailment, careful se]ection of meat, its thorough cooking, etc.

\section{MORTALITY FROM TUBERCULOSIS.}

From May 1, 1902, till Nov. 1, 1903, 51 Jews died from tuberculosis in the Jewish district of Chicago. This represents an annual death rate of 1.51 per 1,000 living, or 138.5 deaths from this disease in 1,000 mortality from all causes (see Table 1). The corresponding death rate from tuberculosis in the central block (Chart 2) was 2.81 per 1,000 living, or 228.5 deaths from this disease in a total mortality of 1,000 . During the same period of time the annual mortality from tuberculnsis among the non-Jewish population of the Jewish district was 5.02 per 1.000 living, or 179.7

1. The per cent. of two-story dwellings in the entire Jewish dis trict is 90 . The greater density of population in the Jewish dis trict of New York ( 488 per acre) is made possible by the existence of numerous large tenement buildings. 


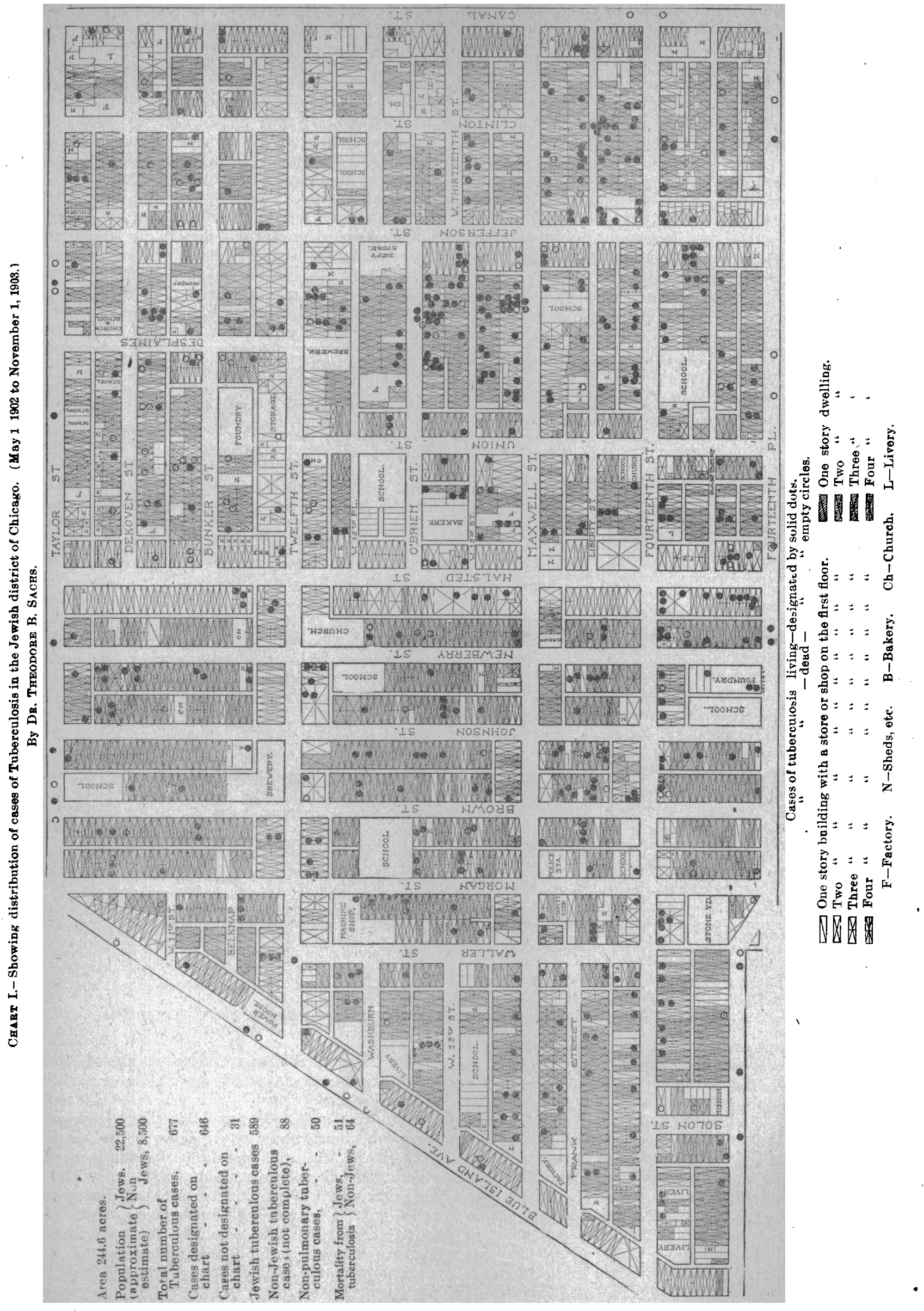

Downloaded From: http://jama.jamanetwork.com/ by a Florida International University Medical Library User on 06/17/2015 
deaths from tuberculosis in a total mortality of 1,000 .

The annual death rate from tuberculosis in the city of Chicago, according to the United States census for 1900 , is 1.78 per 1,000 living, or 110.2 deaths from tuberculosis in a total mortality of 1,000 .

These figures would naturally lead to the conclusion that mortality from tuberculosis among Jews is comparatively low and that Jews enjoy a certain immunity from this disease. Statements of this nature are found in nearly every text-book and apparently conform with the experience of the most careful observers in the profession of this country and Europe.

No deductions on this subject could be drawn from the federal census, as the population is classified only above the average, judging from their occupations and the fact that out of 10,618 families, 6,622 employed from one to three servants, or more.

While this bulletin contains an enormous amount of material collected by experienced statisticians and its value is enhanced by commentaries from one of the foremost medical men in this country, the conclusions concerning rarity of tuberculosis among Jews can not be accepted for the following reasons: 1 , the defective method of inquiry; 2, the high economic status of the families investigated, and, 3 , the prevailing tendency to conceal tuberculosis as a cause of death.

An extensive study of tuberculosis among the poor and middle-class Jews of New York was recently made

Charr II.-A detailed study of a single block in the centre of the Jewish district of Chicago.

By Dr. Thronore B. Saogs and MIss Bertha Bazard, resident of Hull House.

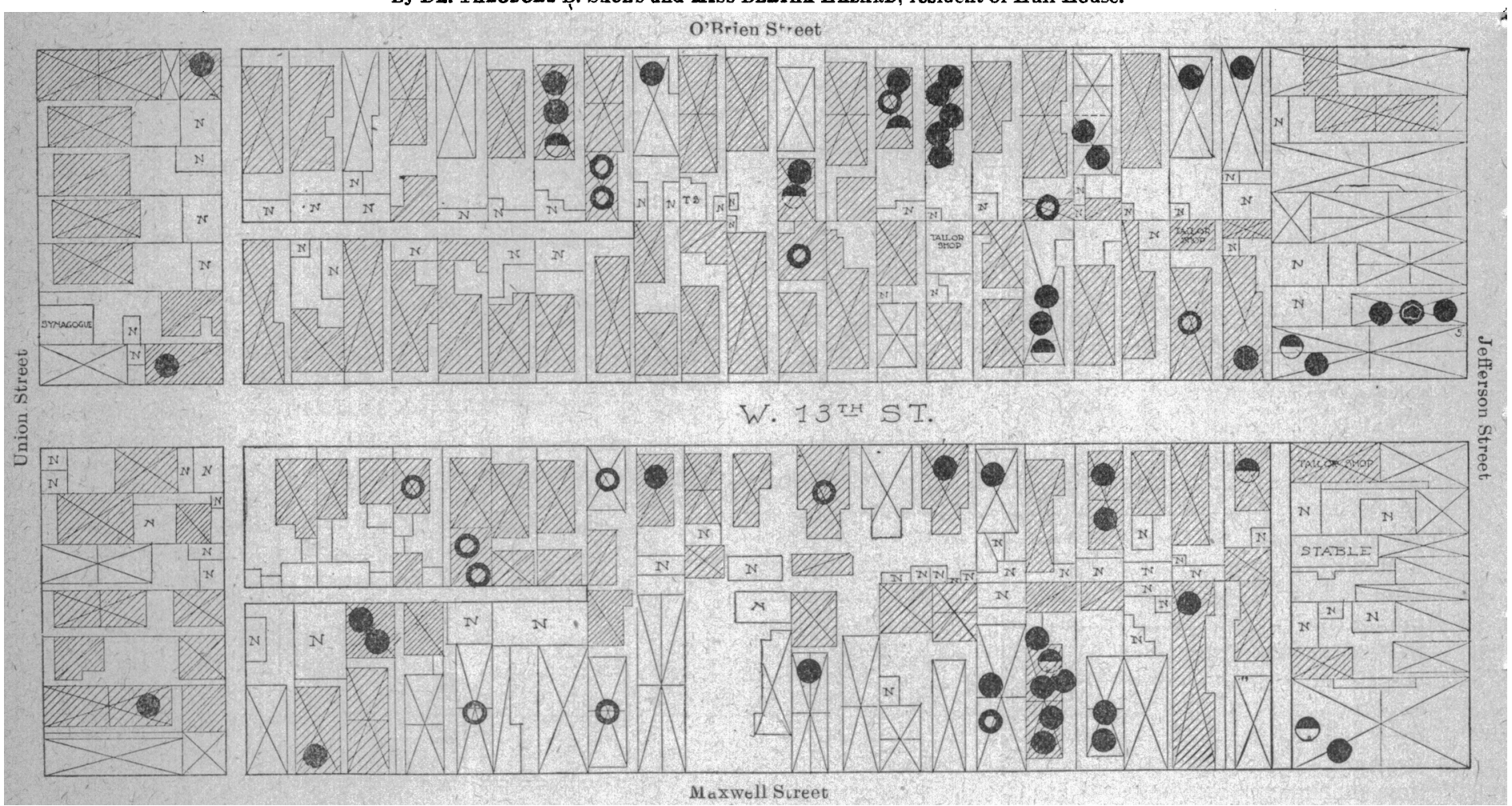

Area, 8 acres-Population 2,221.
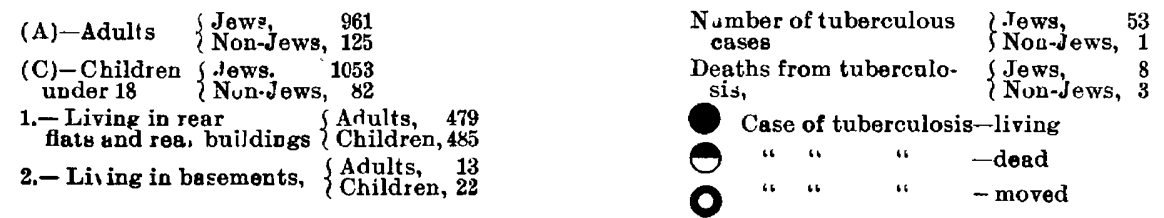

Cases of tubereu'osis designated on 1 his chart occured in a period of 18 months. (May 1, 1902 to November 1,1903 ).

according to the place of nativity. A very large amount of statistical material is found in one of the most extensive investigations of this subject made by Dr. J. S. Billings, who, in Bulletin 19, Federal Census 1890 , presents the results of a census of 60,630 Jews. The bulletin gives an astoundingly low annual rate of mortality from tuberculosis among Jews, namely, 0.22 per 1,000 living, or 70.59 deaths from this disease in a total mortality of 1,000. All the data in this census were obtained through special inquiries directed to heads of Jewish families living in widely different parts of this country. The decision as to the cause of death in each case was left to the judgment and fairness of heads of these families. Their economic status was far by Dr. Maurice Fishberg. ${ }^{2}$ He presents the results of a comparative study of the mortality statistics in the different wards of New York City.

Seventh, Tenth, Eleventh and Thirteenth wards, to a greater extent inhabited by Jews, showed in the years $1897-98$ and '99 a smaller number of deaths from tuberculosis than any other section of the city. The annual mortality per 1,000 living for each of these wards was $2,14,1.72,1.55$ and 1.11 respectively, while the ratio for the Fourth Ward, inhabited by Irish and Italian laboring people, was 5.65, the highest in the city. Returns next to the highest came from the Twenty-third

2. The relative infrequency of tuberculosis among Jews. Amerlcan Medicine, Nor. 2. 1901. 
Ward, inhabited by Irish, Germans ame Americans (4.95 per 1,000$)$.

Any medical man who was brought into close contact with the Jewish poor of large cities will bear witnicss to the fact that only a certain proportion of Jewish tuberculous population die in the district in which they have contracted the disease. Their fear of consumption is much greater than among any other nationality and the belief in climate as the only cure for pulmonary disease is so firmly rooted that the first suggestion of anything abnormal with the lungs leads them to immediate preparation for a change to better climatic conditions. Men and women in very destitute circumstances will sell all their belongings and without second thought start on a journey to some of the distant western states. If for some reason they fail to secure financial assistance from some Jewish charity organization, their relatives and friends come to their rescue.

The idea of proper climate as the only cure for any

TABLE 1.

\begin{tabular}{|c|c|c|c|}
\hline & 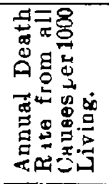 & 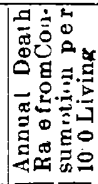 & 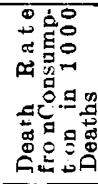 \\
\hline \multirow{3}{*}{ 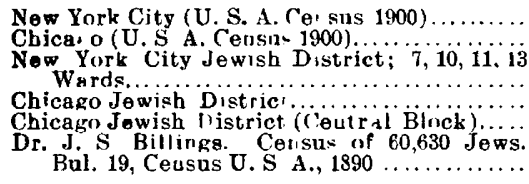 } & $\begin{array}{l}204 \\
162\end{array}$ & $\begin{array}{l}2.43 \\
178\end{array}$ & $\begin{array}{c}118.8 \\
110.2 \\
0\end{array}$ \\
\hline & 10.58 & $\begin{array}{l}1.63 \\
151 \\
2.81\end{array}$ & $\begin{array}{c}99 \\
\mathbf{1 3 8 . 5} \\
228.5\end{array}$ \\
\hline & 6.80 & 0.22 & 70.59 \\
\hline
\end{tabular}

ehronic cough is so widespread that plans for change of residence are frequently made without consulting a physician, and at times against his advice. A large number will remove to more healthful quarters of the same city. This constant emigration of tuberculous population from the poor districts of the city results in the erroneous conclusion that mortality from tuberculosis even among poor Jews is very low. From my experience as examining physician for the United $\mathrm{He}$ brew Charities and National Jewish Hospital for Consumptives I am certain that only a fraction of the Jewish tuberculous poor die in the districts in which they contracted the disease, and consequently any conclusions concerning prevalence of tuberculosis among Jews, based only on the rate of mortality, are necessarily erroneous to a considerable extent.

TABLe 2.-Moratity from Tumercliosis and PNeumonia in THE JeWish District of Chicago. (May 1, 1902, Nov. 1, 1903.) (Among Jews.)

\begin{tabular}{|c|c|c|c|c|c|c|c|c|c|c|}
\hline Aa Es. & $\begin{array}{c}U n- \\
d e r\end{array} \mid$ & $5-10$ & $10-15$ & $15-20$ & $20-30$ & $30-40$ & $40-50$ & $.50-60$ & $\overrightarrow{0}$ & Total \\
\hline $\begin{array}{l}\text { Tuberculosis... } \\
\text { Pnoumovia ... }\end{array}$ & $\begin{array}{l}1 x \\
i 2\end{array}$ & 5 & $\begin{array}{l}3 \\
\cdots\end{array}$ & $\begin{array}{l}4 \\
\cdots\end{array}$ & $\begin{array}{l}4 \\
1\end{array}$ & $\begin{array}{l}6 \\
3\end{array}$ & $\begin{array}{l}6 \\
4\end{array}$ & $\begin{array}{l}4 \\
2\end{array}$ & $\begin{array}{l}1 \\
3\end{array}$ & $\begin{array}{l}51 \\
46\end{array}$ \\
\hline
\end{tabular}

The accompanying table of ages of mortality from tuberculosis in the Jewish district of Chicago well illustrates this point (Table 2). Of 51 deaths from this disense, 26 occurred before the age of 15 , while in the period of life between 20 and 40 years, or the usual period of greatest mortality, only 10 deaths took place. The reason for a high mortality among children is explained by the frequent occurrence of meningeal tuberculosis. On the other hand, the number of persons that die in the district between 20 and 40 years of age would be very large if not for that constant emigration of tuberculous

- adults.
It is jossible that certain conditions of Jewish life, particularly rarity of alcoholism and their dictary laws, may have some influence on prevalence of this dreadful disease, but the rate of mortality is much greater among them than was so far recorded.

For a period of eighteen months beginning May 1, 1902 , an effort was made to record every case of tuberculosis that occurred in the Jewish district of Chicago. This was facilitated by the fact that a large proportion of Jewish tuberculous poor sooner or later apply for admission to the National Jewish Hospital for Consumptives. In addition to that the records of numerous city hospitals were consulted and every authentic case treated by myself and other medical men in this part of the city was added to the entire number. In a large prorortion of cases in adults the diagnosis was confirmed by microscopic examination of the sputum and no diagnosis of tuberculosis was made unless based on positive pliysical findings. The results of this investigation lead to the inevitable conclusion that tuberculosis is very prevalent among the Jewish poor, that unsanitary condit' ons of home and factory life are chiefly responsible for its widespread occurrence and that tuberculosis mows rown its victims regardless of race or nationality.

\section{WIDESPREAD OCCURRENCE OF TUBERCULOSIS IN THE DISTRICT.}

In a period of eighteen months 840 Jewish consumptive poor applied for treatment at various hospitals and dispensaries of this city, the majority of them receiving treatment at institutions conducted by United Hebrew Charities. More than one-third of the entire number sought admission to the National Jewish Hospital for Consumptives in Denver. The excellent results obtained by that institution and willingness of the Jewish Charities to extend help to their consumptive pcor became widely known, so that gradually the number of applicants increased to such an extent as to create a very difficult problem to deal with.

Of the total number of 840 cases, 589 came from the Jewish district previnusly described and 129 from an area within a radius of a mile from it.

Classification of ages was as follows:

\section{TABLE 3.}

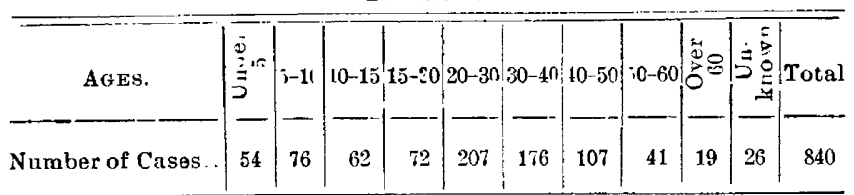

Thus one-third of the entire number of cases occurred in children and 60 per cent. between the ages of 20 and 50 , or the period of life of greatest usefulness to society.

As shown in Table 4, 80 cases were non-pulmonary; in 61 some other organ besides the lungs was prominently involved. Tubercular meningitis was found almost exclusively in the first three years of life. Seventyfive per cent. of cases of glandular tuberrulosis were met in the first two decades of life. Difficulties inherent to differential diagnosis of intestinal diseases in children may explain the apparently small number of cases of intestinal tuberculosis found in the first few ycars of life.

In $t 1$ cases of the entire number physical signs were not definitc enough to make a positive diagnosis; these cases were classed as suspicious.

Of 840 cases, 760 or 90 per cent. were cases of pulmonary tuberculosis. Clinical demonstration of greater frequency of tuberculosis in other organs of the body 
colild be accomplished only by the use of more exact and accessible methods of diagnosis which we do not possess at the present time. The tuberculin test, not entirely free from harmful effect, was out of question in the

TABLE 4.-Cllassification OF the 840 Cases of Tuberculosis ACCORDING TO ORGANS INVOLVED.

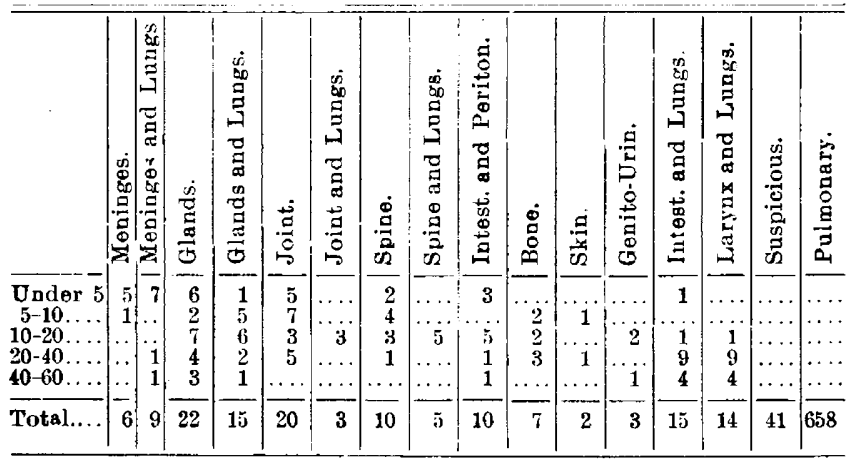

cases under discussion, as the majority of them were patients treated either at free dispensaries or their homes.

According to occupation these cases were classified as follows :

TABLE 5.

\begin{tabular}{|c|c|c|c|}
\hline \multicolumn{2}{|l|}{ Males. } & \multicolumn{2}{|l|}{ FemaLeg. } \\
\hline 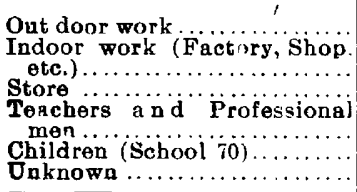 & $\begin{array}{r}65 \\
190 \\
55 \\
9 \\
9 \\
103 \\
68\end{array}$ & 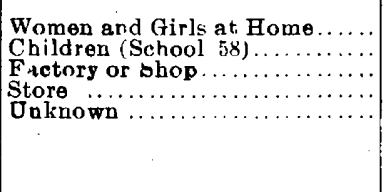 & $\begin{array}{r}210 \\
99 \\
26 \\
13 \\
2\end{array}$ \\
\hline lotal. . & 490 & Total.... & 350 \\
\hline
\end{tabular}

Of those employed in factories or shops 50 per cent. were tailors (operators, finishers, cutters, etc.), 15 per cent. cigar or cigarette makers. At least 70 per cent. of the tailors were operators employed in the so-called sweatshops of the Jewish district. Of the 65 engaged in outdoor work 15 were rag peddlers.

Unfarorable conditions inherent to employment could be considered to a great extent responsible for production of 284 cases, the number found in persons employed in factories, shops and stores. Four hundred and twelve. or 50 per cent. of the entire number of cases, oceurred in women or children at home. These cases could be traced either to spread of infection in the same family, close association with a tubercular family in the same building, or oceupation of premis's previously infected by a consumptive.

The $67 \%$ cases of tuberculosis (589 among Jews and 88 among non-Jews) found in the Jewish district were distributed among 533 houses. Of this number 428 houses contained 1 case each; 75 houses, 2 cases each; 26 houses, 3 cases each; 1 house, 4 cases: 2 houses, 5 eases each; 1 house, 7 cases.

In 105 houses containing more than one case each, the number of infected families was 175 , showing that spread of infection to neighboring families in the same building is probably almost as great as within the tuberculous families themselves.

It would require considerable investigation covering a long period of time in order to determine what proportion of the entire number of cases originated in houses previously infected by consumptives. That premises vacated by tuberculous families served as a frequent soures of infection is shown by the fact that tuberculous family history could be elicited only in about one-lualf of the 412 cases that occurred in women or children at home; the other half could originate either from premises previously infected or close association with neighboring tuberculous patients.

The so-called Jewish district contains 3,996 dwellings; of this number 533 at the time of the investigation included $67 \%$ cases of tuberculosis. As statisties mentioned in this paper refer chiefly to the element of population frequenting charitable medical institutions, it would be a conservative estimate to say that at the present time there are at least 1.000 cases of tuberculosis in the district, or 1 case to 30 living, or one dwelling of every five is being infected. If records for the last few years are consulted, it may not be surprising to find that nearly every house in the Jewish district was at some time occupied by a tuberculous patient. Frequent changes of residence lead to continuous infection of new dwellings; still no effort was ever made toward sy:tematic disinfection of premises vacated by consumptives. Medical men throughout the city familiar with the widespread occurrence of tuberculosis among the poor know very well that all these deductions could be applied with equal strength to all parts of the city where our poor live and work.

That the disease is on a constant increase among the poorer classes of population in this city is my earnest conviction. Unfortunately, very little has been done till lately to counteract its spread.

The United Hebrew Charities' West Side Dispensary took cognizance of this fact three years ago, starting a campaign of education in the Jewish district. By individual instruction and distribution of circulars, the members of the medical staff have endeavored to acquaint the Jewish poor with the nature of the diseass and means of preventing the spread of infection. A large percentage of cases were kept under constant medical supervision. At the same time the United Hebrew Charitjes have done their best to ascertain and supply the needs of consumptives in this district. Through an understanding with the National Jewish Hospital for Consumptives in Denver about 60 incipient cases of tuberculosis, in a period of 18 months, were successfully treated in that institution. Of late the number of applicants increased to such an extent that the Jewish charitable organizations are gradually coming to the conclusion that even if selected cases continue to be sent to the Denver hospital, a sanitarium near Chicago ought to be provided for the vast number of Jewish tuberculous poor. The problem of eradicating the widesprend occurrence of tuberculosis in the poor districts demands immediate solution, and it may be confidently expected that the Jewish charitable organizations, as usual. will contribute their share toward the solution of this great question of to-day.

No subject of medicine received more attention in the last 20 years than tuberculosis, its etiology and means of prevention. Koch's famous discovery gave an increased impetus to the warfare against this disease that for many centuries was decimating the ranks of humanity. To-day the medical profession stands united in a crusade that means saving of millions of lives every year, but ultimate success can follow only a complete change in conditions of life favoring occurrence and spread of this disease.

In Chicago the first opportunity of a systematic warfare against tuberculosis came with the organization of the Committee for Prevention of Tuberculosis of the 
Visiting Nurse Association. During the first year of the existence of this committee the tuberculosis problem has attracted more attention in this city than at any previous time. A large number of tuberculous poor in various parts of the city were reached through its agency, and I am certain its influence is felt already in a higher degree of individual prophylaxis on the part of the public.

Of the many details of the tuberculosis problem, one-the thorough disinfection of houses vacated by consumptires--can be effectively carried on only by the municipal government. The Chicago Medical Society ought to go on record on this question and the Board of Health should be provided with sufficient means to do the work. I know the conscience of the local medical profession and community at large will not tolerate any more the enormous loss of life entailed by continuous reinfection of dwellings in the poor districts of this city.

The mere education of masses on the subject of tuberculosis may help a great deal toward solution of the grave problem confronting us, but any appreciable reduction of the frightful mortality from this disease can follow only a radical change in the hygienic conditions in which our laboring people live and work.

The campaign for better conditions should include: 1 , cleaner strects, frequently sprinkled and swept; 2 , complete abatement of smoke nuisance; 3 , more playgrounds and parks; 4, erection of model dwellings where flats could be rented at a moderate price; 5 , better hygienic conditions in factories and stores-in short, all measures designed to improve the conditions of life of the workingman. I may be permitted also to say that no mensures of public policy concerning tuberculosis could be carried out to their full extent unless the city of Chicago passes a compulsory notification law.

In regard to hospital accommodations the tuberculous patient has been and remains the most neglected individual in the city of Chicago. Home treatment of tuberculosis in the poorer districts of the city can never be carried out with any degree of success unless the conditions in these districts are completely changed.

The Cook County Hospital for Consumptives, even completely reorganized under the plans of the present County Board, could accommodate only a fraction of our tuberculons poor. As the doors of every hospital in Chicago are at present closed to consumptives, the establishment of a large sanatorium outside the city limits is a need that ought to be fulfilled in the near future.

Before closing this paper I wish to emphasize the following points :

1. The so-called immunity of Jews from tuberculosis is greatly overestimated.

2. As tuberculosis is a social disease, the prevalence of which is determined by unfavorable conditions of life, its eradication can only be accomplished by the combined efforts of the state, laity and medical profession.

3. That better housing conditions, dissemination of knowledge concerning tuberculosis and its prophylaxis, compulsory notification, thorough disinfection of premises previously occupied by consumptives, and establishment of public sanatoria for treatment of this disease would put an end to its present widespread occurrence.

My thanks are due to Miss Bertha Hazard (resident of Hull House), for valuable assistance in the investigation of the central block of the Jewish district, and Dr. Alice Hamilton of Hull House, for examining the records of county institutions and Central Free Dispensary.

\section{THE DIAGNOSIS OF SCARLET FEVER AND}

\section{SCARLATINOID AFFECTIONS.*}

JAY F. SCHAMBERG, A.B., M.D.

lrofessor of Dermatology and Eruptive Infectious Diseases, Philadelphia Polyclinic and College for Gruduates in Medicine Assistaut Diagnostician and Consultant Philadel phia Bureau of Health.

PHILADELPHIA.

Of all the acute cruptive fevers, scarlatina, in obscure cases, offers the greatest difficulties in diagnosis. In weil-pronounced and typical cases the nature of the disease is quite clear. When all the symptoms are well developed an unmistakable syndrome is presented. Who could fail to diagnose a disease characterized by sudden romiting, high fever, prostration, diffuse punctiform rash, circumoral pallor, red and swollen throat, enlarged glands and strawberry tongue, followed by desquamation, otitis media and albuminuria? But the picture is frequently incomplete.

Those who have had experience with scarlet fever have observed that in very mild cases all the symptoms are commonly poorly marked. When the eruption is intense the throat is usually severely attacked, the tongue is characteristic and the fever is high. When, on the other hand, the general symptoms are very mild, the rash is, as a rule, faint and poorly developed.

It is under the latter circumstances that the diagnosis becomes difficult, for the complex of symptoms on which the foundation of the diagnosis rests is too weak to support it.

How often do we see cases in which the rash is faint, the constitutional symptoms mild, and the throat and tongue uncharacteristic. The evidence appears very slender on which to base the diagnosis of disease which necessitates six or eight weeks of isolation and sundry other inconveniences. Onder these circumstances the physician will do best to postpone the pronouncement of a diagnosis until the further course of the disease is watched. In some cases it will remain impossible even in the light of subsequent erents to be sure of the scarlatinous nature of the discase. This is a humiliating admission, but the interests of truth demand that the limitations of our knowledge be frankly confessed.

I believe that in no other acute diseases are so many errors of diagnosis made as in scarlet fever. On the one hand, many cases of extremely mild scarlet fever are overlooked. and on the other, rashes from other causes resembling that of scarlet fever are not infrequently diagnosed as the latter disease.

It should be remembered that there is no one symptom of scarlatina which is pathognomonic of the disease.

The rash, the most conspicuous symptom, and the one which has given the affection its name, is not in itself characteristic. inasmuch as a practically identical exanthem mav occur in other conditions. Nor does its absence entirely exclude the diagnosis of scarlet fever. Indeed, we may have a scarlatina without eruption (scarlatina sine eruntione), without fever (scarlatina sine febbre). or without sore throat (scarlatina sine angina).

In the formulation of a diagnosis each of the composite svmptoms of the disease has a relative value. It mav prove of interest to discuss the importance to be attached to some of the manifestations of scarlet fever.

* Read at the Fiftr-fifth Annual Session of the Amerlean Medical Association, in the Section on Cutanenus Medirine and Surgery. and apnroved for publication by the Ixxecutive Committee: Drs. H. W. Stelwagon, J. A. Fordyce and F. G. Anthony. 